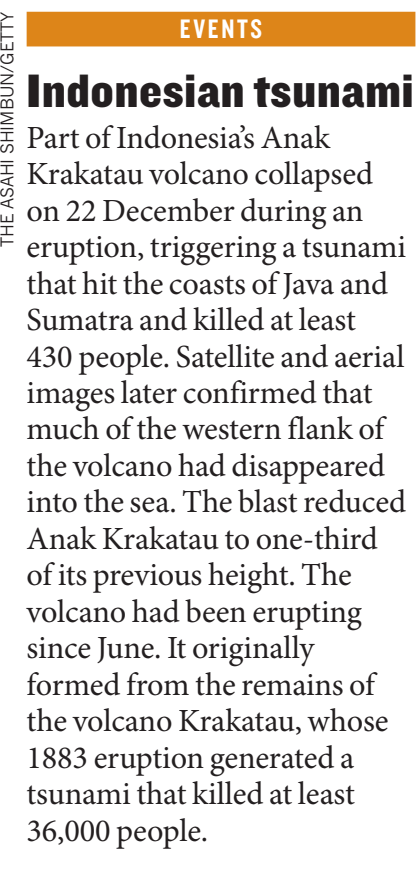
SPACE

\section{Ultima Thule fly-by}

On 1 January, NASA's New Horizons spacecraft flew past the space rock $2014 \mathrm{MU}_{69}$, nearly 6.5 billion kilometres from Earth - the most distant Solar System object ever visited. Early images, taken

before the spacecraft whizzed just 3,500 kilometres above $\mathrm{MU}_{69}$ 's surface, showed an elongated blob that resembles a bowling pin. The object - which researchers have nicknamed Ultima Thule - is spinning almost directly face on to Earth, like a propeller blade.

\section{POLICY}

\section{Japanese whaling}

Japan has been condemned for its decision to withdraw from the International Whaling Commission (IWC) and resume commercial whaling. The government announced on 26 December that it will begin commercially hunting the mammals in its waters this year, but will end its whaling programme in the Southern Ocean. The IWC, based in Cambridge, UK, introduced a moratorium on whaling in 1986, but Japan has continued to hunt the mammals, citing scientific purposes (pictured, minke whale at Kushiro Port). Last year, the IWC rejected the government's bid to restart

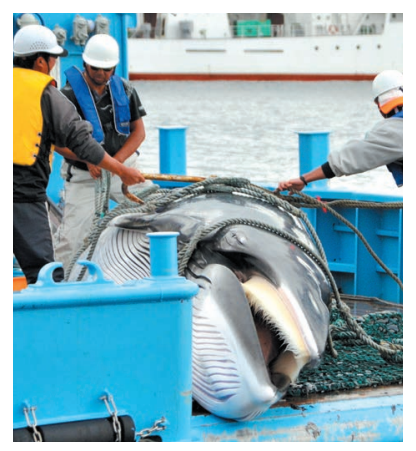

commercial whaling. Japan says it will now participate in the IWC only as an observer.

\section{POLITICS}

\section{US shutdown}

Several major US science agencies shut down indefinitely on 22 December after politicians failed to reach a deal to continue funding government operations. NASA, the National Science Foundation, the Environmental Protection Agency and the Food and Drug Administration are among the agencies affected by the shutdown - the third in 2018. By law, they must curtail all activities except those considered essential for protecting life and property. It is not clear when the funding impasse will end; President Donald Trump says that any budget deal must include US $\$ 5$ billion to construct a wall along the US border with Mexico, but Democrats in Congress say they will not vote for such a plan.

\section{Ebola troubles}

Political protests are thwarting Ebola control efforts in Beni and Butembo, northeastern cities in the Democratic Republic of the Congo. On 28 December, the World Health Organization reported that it is struggling to carry out measures such as identifying people potentially infected with the virus. In Beni, protesters robbed and set fire to an Ebola centre. The unrest follows President Joseph Kabila’s decision to suspend voting in presidential elections in Beni, Butembo and Yumbi, which are opposition strongholds. Observers suspect that his motivation is to suppress votes.

\title{
TREND WATCH
}

Emerging and developing economies showed the largest increases in research output in 2018. Pakistan and Egypt topped the list in percentage terms, with rises of $21 \%$ and $15.9 \%$, respectively. China's publications rose by about $15 \%$, with India, Brazil, Mexico and Iran all seeing their output grow by more than 8\% compared with 2017.

This diversification of players in science is a phenomenal success, says Caroline Wagner, a science-policy analyst at the Ohio State University in Columbus. "In 1980 , only 5 countries did $90 \%$ of all science - the United States, the United Kingdom, France,
Germany and Japan," she says. "And now there are 20 countries within the top producing group." Globally, the output rose by around 5\% in 2018, to an estimated 1,620,730 papers listed in the Web of Science sciencecitation database. The data were compiled for Nature by Clarivate Analytics, owner of Web of Science, which says the overall rise is comparable to increases over the past few years, and is likely to continue in 2019. It's not yet clear what is driving the rises in emerging nations; they could be partly due to changes in how the database is curated, to add more local and national journals.

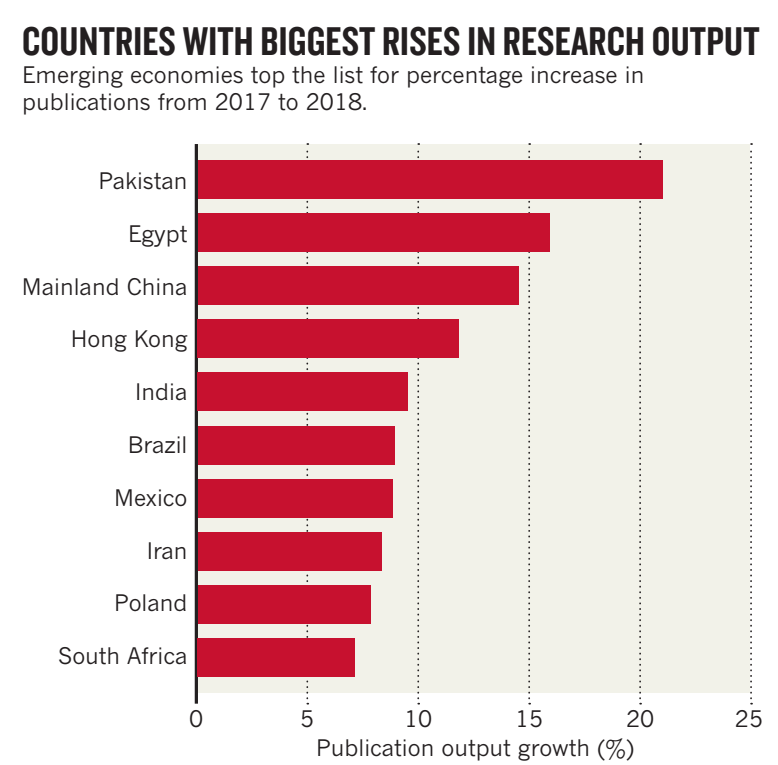

